\title{
Non-performing Loans and Systemic Risk: Comparative Analysis of Serbia and Countries in Transition CESEE ${ }^{3}$
}

\author{
Article history \\ Received: 1 August 2013 \\ Sent for revision: 5 September 2013 \\ Received in revised form: 24 November 2013 \\ Accepted: 24 November 2013 \\ Available online: 26 November 2013
}

\begin{abstract}
This paper presents the results of the research on the impact of non-performing loans to the systemic risk in the domestic banking system and a comparison with other countries in transition, as well as on certain EU countries. It is important to metion that the extreme bank-centricity caused the extension of the analysis to the entire financial sector of Serbia. Therefore, macroeconomic and macro-financial component of systemic risk were separated. In order to more precisely determine the main effects of non-performing loans in the propagation of systemic risk, the authors have created and used two new synthetic indicators in the research. The first is the macroeconomic contagion with non-performing loans (problematic loans expressed as a percentage of GDP), and the second is the infection of financial sector with nonperforming loans (the proportional share of these loans in the assets of the financial sector). Analysis of the period just before and during the current financial crisis and the recession (2007-2012) showed that the NPLs (nonperforming loans) are the main generator of systemic risk in the financial and real sectors of Serbia. In addition, the survey results show that the applied synthetic indicators measure total system risk and its basic components more accurately then the analytical, which have only been in use until now. Comparative analysis showed similar results, not only in the countries in transition, but also in developed ones. The results of this study provide guidance and represent an important input for economic policymakers, because the system-
\end{abstract}

\footnotetext{
${ }^{1}$ Institute of Economic Sciences, Belgrade, Serbia, vlastimir.vukovic@ien.bg.ac.rs

${ }^{2}$ Institute of Economic Sciences, Belgrade, Serbia, ivana.domazet@ien.bg.ac.rs

${ }^{3}$ This paper is a part of research projects numbers III47009 and OI179015 financed by the Ministry of Science and Technological Development of the Republic of Serbia.
} 
Vuković V., Domazet I.: Non-performing loans and systemic risk: comparative...

ic risk is the greatest immediate threat to economic prosperity and financial stability of each country.

Keywords: non-peforming loans, systemic risk, macroeconomic contagion, banks, financial sector.

\section{Problematični krediti i sistemski rizik: komparativna analiza Srbije i tranzicionih zemalja CESEE}

Apstrakt: Ovaj rad prikazuje rezultate istraživanja uticaja problematičnih kredita na sistemski rizik u domaćem bankarstvu i poređenje sa drugim zemljama u tranziciji i nekim zemljama EU. Ekstremna bankocentričnost je uzrokovala proširenje analize na celokupan finansijski sektor Srbije. Pri tome su razdvajane makroekonomska i makrofinansijska komponenta sistemskog rizika. $U$ cilju preciznijeg utvrđivanja osnovnih efekata loših kredita $u$ propagaciji sistemskog rizika autori su osmislili i koristili u istraživanju dva nova sintetička pokazatelja. Prvi je makroekonomska zaraženost problematičnim kreditima (problematični krediti iskazani u procentima BDP-a), a drugi zaraženost finansijskog sektora problematičnim kreditima (procentualni udeo ovih kredita $u$ aktivi finansijskog sektora). Analiza vremenskog perioda neposredno pre $i$ tokom aktuelne finansijske krize $i$ recesije (2007-2012) pokazala je da su problematični krediti glavni generator sistemskog rizika $u$ finansijskom i realnom sektoru Srbije. Uz to, rezultati istraživanja dokazuju da primenjeni sintetički pokazatelji preciznije mere ukupan sistemski rizik i njegove osnovne komponente nego analitički, koji su do sada isključivo bili korišćeni. Komprativna analiza je pokazala iste rezultate ne samo u tranzicionim, već i razvijenim zemljama. Rezultati ovog istraživanja daju smernice i predstavljaju značajan input kreatorima ekonomske politike, jer je sistemski rizik najveća neposredna pretnja ekonomskom prosperitetu $i$ finansijskoj stabilnosti svake zemlje.

Ključne reči: problematični krediti, sistemski rizik, makroekonomska zaraza, banke, finansijski sektor.

\section{Introduction}

This work was primarily motivated by the mark that "the issue of systemic risk is probably the most important and the most difficult that we confront" (Caruana, 2010, p. 1). The first man of the Bank for International Settlements (BIS) backed his assessment by saying that aggregate risk that the system is faced with, is much more than the simple sum of individual risks. Research confrontation with this challenging topic is even more difficult if we take into 
Vuković V., Domazet l.: Non-performing loans and systemic risk: comparative...

account that systemic risk was underestimated everywhere before this crisis (Caruana, 2010, p. 1).

Explanation surprisingly rapid spread of systemic risk is impossible without an analysis of its causal connection with the movement of so-called NPLs - Nonperforming loans, which was also devoted more attention after the outbreak of the global financial crisis. Putting these causal links in the focus of the research was aimed at better understanding of the ways in which systemic risk spreads and its more accurate measurement. In this way, the prerequisites for finding appropriate prudential measures necessary for ensuring the desired financial stability are being created.

According to the original working definition of systemic risk, which is generally accepted to date, it is "the risk that an event will trigger a loss of economic value or confidence in, and attendant increases in uncertainly about, a substantial portion of the financial system that is serious enough to quite probably have significant adverse effects on the real economy" (Group of Ten, 2001,p.126). Particular emphasis is placed at disorder in payment systems, credit flows and asset prices. At the same time, the authors emphasize that this is a two-dimensional definition. First one is dimension of interdependence (networks), arising from interconnection of financial institutions. A typical example is the systemic liquidity risk (Cao \& Illing, 2011). The second is the time dimension, resulting from the cyclical development of the financial system, coupled with macroeconomic cycles. Because of its procyclicality the financial system can trigger and stimulate aggregate demand, output and unemployment fluctuations. Hence, this overflow of unwanted financial effects on the real sector can be characterized as negative externalities (Caruana, 2010, p. 1).

Most of the other authors also considered that the primary characteristic of systemic risk is its potential for the spread of infection among financial institutions and its spillover to the real economy (Browne, Llewellyn \& Molyneux, 2011, p. 119). Contagion among financial institutions depends on their exposure to credit risk, as well as other factors such as liquidity management, the cross-border participation and shareholder links, contingent credit lines, deposit insurance and access to payment services (Dijkman, 2010, p. 23-24).

Non-performing loans (NPLs) were the immediate cause of the rapid spread of systemic risk in the banking and overall financial sector in Serbia. Given that the analysis using a standard NPL ratio showed extreme exposure to systemic risk, much higher than in the case of other transition, but also developed European countries, the objective of this study included more precise measuring of the systemic risk potential, as well as its impact on macroeconomic performance. For this reason, this paper defined two new synthetic indicators. The first is the contagion of financial sector with non-performing loans (percentual share of NPLs in the assets of the financial sector - NPL/AFS), used 
measuring propagation of systemic risk within the financial system. The second is the macroeconomic contagion with non-performing loans (NPLs expressed as a percentage of GDP - NPL/BDP), used for the assessment of systemic risk potential spillover to the real sector. Empirical analysis has confirmed that the new indicators measure the systemic risk potential and its impact on macroeconomic performance more accurately. The results of such measurement of systemic risk potential present a strategic base for the creation of effective and rational economic policy, above all in the area of banking.

Accordingly, the paper is structured in accordance with the research goals. The first part of this paper outlines the theoretical basis of systemic risk, and research methods. The elaboration of the study analyzes the connection between systemic risk and non-performing loans in the banking sector in Serbia. After that, the authors carried out a comparative analysis of Serbia and other countries (not just those in transition, but also those of the most developed), with key indicators that were used to date. This is followed by further analysis of systemic risk and non-performing loans based on two new synthetic indicators, which confirmed that the new indicators measure the potential of systemic risk and its impact on macroeconomic performance more accurately, as it is shown in the survey results summarized at the end of the paper, along with proposed innovation of existing macro-prudential measures.

\section{Methodology}

There are a variety of methodological approaches for measurement of systemic risk. One of the most comprehensive frameworks specifies: 1) One of the most comprehensive framework states: aggregate indicators of financial health (interest rates and prices of financial assets; financial funds and flows; reports on the opinion of investors and credit managers; macroeconomic indicators), 2) measuring the position of individual institutions, and 3) evaluation of systemic connections (European Parliament, 2009, p. 4-6). For example, exceptionally substantial reports on the opinion of investors, bank managers and other financial intermediaries regarding systemic risk are published by the respective central banks (see: Bank of England, 2013). A similar framework, which is being offered by the IMF, includes the following: 1) information on the profits of banks, 2) indicators of economic activity, non-performing loans, stock prices, real estate prices, 3) inter-bank exposures and balance sheet data, and 4) other indicators (IMF, 2010, p.3).

The feedback effect in case of macroeconomic contagion from the real to the banking sector, increases the credit risk by worsening macroeconomic performance, among which are commonly referred to: 1) real GDP growth, 2) CPI inflation, 3) interest rates on loans, and 4) changes in nominal exchange course (Buncic \& Melecký, 2012, p. 16-17). The four variables are standard in 
Vuković V., Domazet l.: Non-performing loans and systemic risk: comparative...

all value at risk models and stress tests of credit risk, which show NPL elasticity regarding these variables (Buncic \& Melecký, 2012, p. 25).

Given that the credit risk, "is the risk of potential adverse effect on the financial result and capital of the bank due to the debtor's failure to meet obligations to the bank" (the Banking Act, Official Gazette of RS, no. 107/2005 and $91 / 2010$, Article 31), it is obvious that the NPLs are not only an indicator, but the expression of credit risk. As a reminder, loans are classified as problematic if: 1) the borrower delinquents in the payment of interest or principal payments over 90 days, 2) Quarterly (and higher) interest, which was attributed to debt is refinanced or payment is delayed, and 3) the bank estimated that the borrower will not be able to fulfill the obligations, partially or completely (NBS, 2012, p. 48).

Macroeconomic determinants of non-performing loans also indicate on the relationship between the NPLs and systemic risk: real GDP growth, prices of stocks, exchange rates and interest rates on loans (Beck, Jakubik \& Piloiu, 2013 , p. 20). The movement of real GDP is still the most important factor, while, for example, the prices of stocks are more important in economically developed countries, while the exchange rate is more important in the euro and the dollar influenced economies. Therefore foreign currency loans are a source of systemic risk in the transition economies of Central, Eastern and Southeastern Europe - CESEE (ESRB, 2011, p. 31).

As determinants of NPLs in the developed economies, the following can be highlighted: 1) changes in prices in the housing market, 2) private sector credit growth, 3) the GDP course, and 4) inflation (Nkusu, 2011, p. 20). The study of the same author confirmed that NPLs play a central role in the credit friction and deterioration of macroeconomic performance, for enhancing the risk of financial instability.

The NPLs researchers who study the NPLs and systemic risk in the developed countries in particular analyze systemically important financial institutions (IMF, 2010, p. 10). BIS, in cooperation with the IMF and other international institutions has developed appropriate methodology for the identification of such institutions, markets and instruments (BIS, 2009). In addition, the indicators of systemic risk based on data on these institutions were also generated. For example, SRISK index shows the expected capital deficiency in systemically important companies in the event of a significant drop in the market, which is why this indicator is the function primarily concerning the size of the company and then their degree of leverage and the marginal expected shortfall - MES (Brownless \& Engle, 2011, p. 52). However it cannot be accepted that the systemic risk is the resultant of risk in systemically important financial institutions, which are interconnected and globally networked. This approach implies the inevitable oligopolistic structure of financial markets, which is the origin of the request for the protection of "too big to fail." That is why the most 
popular report on systemic risk made twelve years ago pointed to the regularity that this risk is higher in more concentrated financial systems since the collapse of one company or one market can threaten the entire system (Group of Ten, 2001, p. 126). If you ignore the above principle, the policy of protection of competition in financial markets will be superseded by the policy of protection of systemically important financial institutions!? The essential problem lies in the "systemically important companies" and their management (Beck, Jakubik \& Piloiu, 2013, p. 21).

Recent systematization of NPL factors in CESEE countries distinguishes the factors at the level of banks (or microeconomic factors) and macroeconomic factors. In the first group are classified: bad management, lack of credible loan applicants, credit expansion, a tendency to moral hazard and similar factors. The second group includes economic cycles, as the most important, followed by exchange rates, interest rates and inflation (Klein, 2013, p. 5). Empirical analysis of this author has shown a strong causal link between the NPL and trends in real GDP (p. 12).

The authors of this paper have set the focus of their research of systemic risk to macroeconomic infection that is caused by NPLs for two main reasons. The first is the potential that they have in the spread of systemic risk in the real sector (procyclic activity), and the second is the dominance of loans as external source of financing. Sufficient evidence is the structure of external sources of financing of the real sector in economically developed countries in the period 1970-2000. The share of loans in these sources ranged from $56 \%$ in the U.S. to $86 \%$ in Germany and Japan. In these countries prevail bank loans, with the exception of the United States with greater involvement of non-bank loans. The rest consists of debt securities and shares - with only $14 \%$ in Germany and Japan and 44\% in the U.S. (Mishkin, 2007, p. 182).

The data contained clearly confirm that the NPLs are the primary source of systemic risk. Additional arguments are provided by the dominance of banks among financial institutions, measured by the proportion in the total assets and other relevant indicators. The influence of banks and banking groups is even greater due to their partial or total ownership of a majority of nonbanking financial institutions. Financial systems in the world are mainly bankbased, with the exception of the U.S., as the banks are the dominant financial intermediaries.

In order to measure the propagation of systemic risk within the financial system, this paper uses a new synthetic indicator - infection of the financial sector with non-performing loans (NPL proportional share in the assets of the financial sector with - NPL / AFS), while for the assessment of systemic risk potential spillover to the real sector, the authors have also used a new synthetic indicator - macroeconomic contagion with non-performing loans (NPL expressed as a percentage of GDP - NPL / GDP). The first indicator is calculat- 
ed for Serbia only, since the data available for other countries were not reliably comparable. Another indicator is derived from the two analytical indicators of the World Bank - Domestic credit provided by banking sector in GDP percent and Bank NPLs to total gross loans in percent. This last indicator is known as the NPL ratio (NPL / Loans) and was used together with NPL as a percentage of GDP for the comparative analysis of the domestic economy, not only with transition CESEE countries, but also with the elected members of the EU, including the economically most developed countries.

For the analysis of systemic risk and the NPLs in Serbia, the authors, in addition to the newly introduced and the World Bank indicators, have also used the key data published by the National Bank of Serbia (NBS). Special heed was paid to examining the sectorial structure of the NPLs, as it provides valuable information on the nature and potentials of systemic risk. Finally the article gives a graphical representation of focused indicators per years, which provides visual insight in the correlation and causal relationship of systemic risk and the NPLs. In doing so, particular attention was given to a review of the comparative analysis based on secondary data, which were obtained by quantitative studies of the World Bank and the National Bank of Serbia. This methodological approach represents an exploratory research on systemic risk issues of different countries, and above all, of Serbia, in the conditions of global economic crisis.

\section{Results and Discussion}

\section{1. Non-performing Loans and Systemic Risk in the Banking Sector of Serbia}

Unfortunately, data on the NPLs in Serbia are systematically monitored since 2008 (NBS, 2013), making the analysis unavailable for longer time series, which would cover the period before the Great Recession. Among the Financial Stability indicators of the Republic of Serbia (RS), NPL indicators are given in the reports on the banking sector as indicators of the quality of assets and funding sources. Crucial are the NPL ratio and NPL coverage with allocated reserves, which are displayed in the table below.

A significant increase in the participation of NPLs in total loans is evident from year to year. Stagnation and a fall in the share of NPLs at the end of 2012 was the result of the liquidation of New Agrobank and exclusion of its NPLs from the calculation (NBS, 2013, p. 13). At the end of the first quarter of this year, the same ratio has reached record breaking $19.9 \%$. Hence, it is understandable why has the National Bank of Serbia ranked high proportion of nonperforming loans in its Annual report on the state of the financial system in 
Vuković V., Domazet I.: Non-performing loans and systemic risk: comparative...

2012, among other key risks. This situation reflects negatively on the tendency of banks to take risks, endangers the profitability of the banking sector and threatens to grow into a systemic risk (NBS, 2013, p. 4). Consequently, all the measures of the NBS are aimed at banks and their protection, and none is intended to loan users.

Table 1. The key NPL indicators RS (\%)

\begin{tabular}{|l|c|c|c|c|c|c|}
\hline Ratio / Year & 2008 & 2009 & 2010 & 2011 & 2012 & $I 2013$ \\
\hline NPL ratio & 11.3 & 15.7 & 16.9 & 19.0 & 18.6 & 19.9 \\
\hline NPL coverage & 153.6 & 142.5 & 133.6 & 121.4 & 120.7 & 117.3 \\
\hline
\end{tabular}

Source: NBS (2013c), p. 5.

NPL coverage with allocated reserves (Table 1) shows that these loans are greater problem for the real sector than for banks. Presented evaluation is confirmed by the extremely high capitalization of domestic banks, measured by capital adequacy, which is for the last few years maintained at a level of about 20\% (NBS, 2013, p. 53).

Table 2. Sectorial structure of NPLs in RS (\%)

\begin{tabular}{|l|c|c|c|c|}
\hline Sector / Year & 2009 & 2010 & 2011 & 2012 \\
\hline Industry & 75.9 & 72.3 & 65.1 & 56.4 \\
\hline Retail & 16.0 & 14.5 & 12.3 & 13.4 \\
\hline Other & 6.8 & 6.3 & 6.3 & 7.3 \\
\hline Other clients (in liquidation) & 0.3 & 6.9 & 16.3 & 22.9 \\
\hline Total & 100.0 & 100.0 & 100.0 & 100.0 \\
\hline
\end{tabular}

Source: NBS (2013a), p. 41.

The threat of rising NPLs is to certain extent mitigated by the decline of credit activity, primarily due to the reduction of corporate loans. Else, the collapse of the credit operations of banks is prevented only through the subsidized loans (NBS, 2013b, p. 26). Sectorial contribution to total NPLs requires examination of their structures shown in Table 2.

Distribution of NPLs by sector indicates their concentration within the economy. If we bear in mind that most of other clients are legal entities in bankruptcy, usually from the industry, we get a dominant share of approximately $80 \%$. The rest relates to retail and others (foreign entities sector, financial sector, etc.). NPLs ratio by sectors is listed below. 
Vuković V., Domazet l.: Non-performing loans and systemic risk: comparative...

Table 3. NPL ratio by sector (\%)

\begin{tabular}{|l|c|c|c|c|}
\hline Sector/Year & 2009 & 2010 & 2011 & 2012 \\
\hline Companies & 20.9 & 21.8 & 24.6 & 21.2 \\
\hline Retail & 8.1 & 7.9 & 7.9 & 8.5 \\
\hline Foreign entities sector & 13.5 & 8.0 & 8.1 & 8.6 \\
\hline Financial sector & 21.8 & 12.2 & 7.6 & 12.9 \\
\hline Other clients (in liquidation) & 16.4 & 79.9 & 89.0 & 93.6 \\
\hline NPL ratio in total & 15.7 & 16.9 & 19.0 & 18.6 \\
\hline
\end{tabular}

Source: NBS (2013a), p. 44.

As expected, loans to corporate entities have proven to be the most risky, with the share of the NP from one-fifth to a quarter. With the inclusion of other clients, mainly from the industry, common of the NP ratio is dizzily increasing. In contrast, the retail sector was almost three times safer loan beneficiary. Foreign persons have also visibly reduced the of the NP ratio, while the financial sector had large fluctuations, but well below the average, excluding the crisis year 2009. Due to the impact of the NPL industry on the systemic risk, it was appropriate to consider their structure as well.

Within the industry, $90.6 \%$ of NPL refers to four areas - mining and processing industry (30.1\%), construction (22.3\%), trade (23.9\%) and real estate business (14.3\%). One can observe the concentration NPL related to the real estate, in excess of $36 \%$ of the loans in the industry. All other areas are represented by $9.4 \%$ of all NPL (NBS, 2013, p. 42). The fact that the construction and real estate business represent the most risky debtors is confirmed by their record NPL indicators $-45.1 \%$ in construction and $37.4 \%$ within the real estate industry. Therefore, we can estimate that these areas are the most important sources of systemic risk in Serbia. NPL ratio also had the significantly lower in the mining and manufacturing (18.5\%), trade (17.5\%), and other areas of the economy (NBS, 2013, p. 44). Absolute and relative magnification of NPL during the crisis have not only increased the danger of systemic risk in the financial system, but also had the effect on macroeconomic contagion spreading to the real sector. Naturally, the feedback effect had the same contagion spilled over to financial institutions in Serbia, especially in banks, again. However, more accurate scale of NPL contagion of financial and real sector can only be determined by using synthetic indicators (Section 4). 
Vuković V., Domazet I.: Non-performing loans and systemic risk: comparative...

\subsection{Comparative Analysis: Serbia and Other Countries}

Comparing the NPL ratio of Serbia and of other countries could be evaluated a real threat of systemic risk in the domestic financial system. That is why the World Bank data for transition countries in the wider region, selected members of the EU and the U.S., as the economically most developed country, are listed below.

Table 4. Non-performing loans in relation to total bank loans (\%)

\begin{tabular}{|l|c|c|c|c|c|c|c|}
\hline Country / Year & 2006 & 2007 & 2008 & 2009 & 2010 & 2011 & 2012 \\
\hline Bosnia and Herzeg. & 4.0 & 3.0 & 3.1 & 5.9 & 11.4 & 11.9 & 12.6 \\
\hline Bulgaria & 2.2 & 2.1 & 2.5 & 6.4 & 11.9 & 14.9 & 16.9 \\
\hline Macedonia & 11.2 & 7.5 & 6.7 & 8.9 & 9.0 & 9.5 & 9.7 \\
\hline Romania & 1.8 & 2.6 & 2.8 & 7.9 & 11.9 & 14.3 & 16.8 \\
\hline Serbia & - & 8.4 & 11.3 & 15.7 & 16.9 & 19.0 & 18.6 \\
\hline Croatia & 5.2 & 4.8 & 4.9 & 7.7 & 11.1 & 12.3 & 13.2 \\
\hline Hungary & 2.6 & 2.3 & 3.0 & 6.7 & 9.8 & 13.4 & 15.8 \\
\hline Poland & 7.4 & 5.2 & 4.4 & 7.9 & 8.8 & 8.2 & 8.4 \\
\hline Slovenia & 2.5 & 1.8 & 4.2 & 5.8 & 8.2 & 11.8 & 13.2 \\
\hline Czech Republic & 3.6 & 2.4 & 2.8 & 4.6 & 5.4 & 5.2 & 5.1 \\
\hline Turkey & 3.9 & 3.3 & 3.4 & 5.0 & 3.5 & 2.6 & 2.5 \\
\hline Austria & 2.7 & 2.2 & 1.9 & 2.3 & 2.8 & 2.7 & 2.7 \\
\hline Greece & 5.4 & 4.5 & 5.0 & 7.7 & 10.4 & 14.4 & 17.2 \\
\hline Ireland & 0.7 & 0.8 & 2.6 & 9.0 & 8.6 & 16.1 & 18.7 \\
\hline Portugal & 1.3 & 2.8 & 3.6 & 4.8 & 5.2 & 7.5 & 9.0 \\
\hline Finland & 0.2 & 0.3 & 0.4 & 0.6 & 0.6 & 0.5 & 0.5 \\
\hline U.S. & 0.8 & 1.4 & 3.0 & 5.4 & 4.9 & 4.1 & 3.9 \\
\hline
\end{tabular}

Source: /World Bank/Data/Financial Sector/.

At first glance it is clear that Serbia had the highest ratio in relation to the chosen countries since 2007, when the domestic NPL ratio was first published. Characteristically, the domestic NPL ratio exceeds the same for Greece and Ireland for years. In addition, Serbia has the highest NPL among the CESEE countries in transition, with the exception of Montenegro, which is not given in the table view due to incomplete data. According to these data, the Serbian banking sector is most exposed to systemic risk caused by the NPLs. However, the NPL ratio is not sufficient to assess the threat of systemic risk for three main reasons: 1) it ignores the financial indepth or development of lending operations as measured by percentage of GDP, 2) it does not include the share of the banking sector in the financial system, and 3) it expresses the potential systemic crisis spilling over to the real sector only partially. 
Vuković V., Domazet I.: Non-performing loans and systemic risk: comparative...

Why the domestic financial system did not succumb to systemic crisis? At the peak of the crisis in late 2008, the Serbian banking sector had a much better liquidity ratio of any EU member state. Capital adequacy was also extremely high (Vuković, 2011, p. 291-292). High liquidity and capitalization were not significantly deteriorated during the crisis, which has so far been enough to avoid systemic risk. The introduction of a new synthetic indicator - macroeconomic contagion with non-performing loans (NPLs expressed as a percentage of GDP - NPL / GDP) in the analysis, provides substantially different picture of the potential of systemic risk (Table 5).

Table 5. Non-performing loans expressed as percentage of GDP

\begin{tabular}{|l|c|c|c|c|c|c|c|}
\hline Country / Year & 2006 & 2007 & 2008 & 2009 & 2010 & 2011 & 2012 \\
\hline Bosnia and Herzeg. & 2.2 & 1.9 & 2.1 & 3.1 & 7.4 & 7.8 & 8.4 \\
\hline Bulgaria & 0.9 & 1.2 & 1.6 & 4.5 & 8.4 & 10.6 & 12.0 \\
\hline Macedonia & 2.6 & 2.5 & 2.8 & 3.9 & 4.3 & 4.3 & 4.7 \\
\hline Romania & 0.4 & 0.9 & 1.3 & 1.5 & 6.4 & 8.8 & 9.1 \\
\hline Serbia & - & 2.7 & 4.6 & 7.4 & 10.1 & 10.9 & 11.6 \\
\hline Croatia & 3.6 & 3.4 & 3.7 & 6.0 & 10.2 & 11.9 & 12.7 \\
\hline Hungary & 1.8 & 1.7 & 2.4 & 5.5 & 8.0 & 10.3 & 10.8 \\
\hline Poland & 3.1 & 2.6 & 2.6 & 4.9 & 5.6 & 5.4 & 5.4 \\
\hline Slovenia & 1.8 & 1.5 & 3.7 & 5.4 & 8.0 & 11.0 & 12.3 \\
\hline Czech Republic & 1.7 & 1.2 & 1.6 & 2.8 & 3.4 & 3.5 & 3.5 \\
\hline Turkey & 1.8 & 1.6 & 1.8 & 3.2 & 2.4 & 1.8 & 1.8 \\
\hline Austria & 3.5 & 2.8 & 2.5 & 3.2 & 3.9 & 3.7 & 3.6 \\
\hline Greece & 5.9 & 5.1 & 5.8 & 8.9 & 15.5 & 22.1 & 23.3 \\
\hline Ireland & 1.3 & 1.6 & 5.4 & 20.0 & 20.0 & 35.7 & 37.8 \\
\hline Portugal & 2.0 & 4.6 & 6.4 & 9.4 & 10.9 & 15.3 & 17.9 \\
\hline Finland & 0.2 & 0.3 & 0.4 & 0.6 & 0.6 & 0.5 & 0.5 \\
\hline U.S. & 1.9 & 3.4 & 6.7 & 12.6 & 11.0 & 9.3 & 8.9 \\
\hline
\end{tabular}

Source: Author calculation based on the World Bank Data.

Macroeconomic contagion is much more widespread in Ireland, Greece and Portugal than it is in Serbia, which explains the depth and persistence of recession in these countries. This indicator reached its maximum of a whopping $12.6 \%$ of the world's largest GDP in the U.S. in 2009. The gradual decline over the last three years, explains why the economic recovery was slow and why the unemployment rate was high not only in the States but in the entire world. On the other hand, it is clear that the economies of Finland, Turkey, the Czech Republic and Austria have not been visibly affected by the global financial crisis and the great recession. 
The level of macroeconomic contagion in transition countries at the end of 2012 varies from the lowest in Macedonia (4.7\%) and Poland (5.1\%), up to $12 \%$ in Bulgaria and $12.7 \%$ in Croatia. Serbia and Hungary also have high double-digit indicators of contagion, including Slovenia (12.6\%). However, compared to the NPL ratio, macroeconomic contagion in Serbia is much lower, as the financial indepth of the domestic economy (loans as a percentage of GDP) are among the lowest in Europe.

Comparison of sector NPLs of transition countries shows that the share of the retail sector in Serbia is significantly below average and the share of the industry is above-average of this group (EBC, „Vienna“ Initiative, 2012, p. 13), which is the indicator of greater exposure to systemic risk. However, recent analyses confirm that the financial crisis has had a significant and permanent impact on all European transition economies, by lowering their output by 12$17 \%$ on the long-term (Furceri \& Zdzienicka, 2011, p. 1). Under the conditions of such a recession, the disruption of credit flows and decrease in their quality, or in other words the growth of NPLs, are inevitable (Bordo \& Haubrich, 2010, p.17).

What is particularly worrying is the fact that in the group of CESEE countries, Serbia had the deepest recession (-1.7\%) in 2012, although other countries in the region touched another recessionary bottom, indicating that this is a lasting recession with (for now) double bottom we are talking about (Schreiner, 2013, p. 18). In addition, Serbia is the most euro influenced country in this group (Scheiber \& Stix, 2009, p. 12), which stimulates the growth of NPLs and strengthens the potential of systemic risk.

The presented indicators do not announce systemic banking crisis in the country, because such a crisis involves two conditions: 1) expressed problems in the banking sector (bankruptcy, insolvency) and 2) emergency measures as a response (liquidity assistance, restructuring, nationalization, government guarantees, purchase of assets) which also have to be obtained (Laeven \& Valencia, 2012, p. 4).

To assess the possibility of outbreak of such banking and financial crisis another new synthetic indicator can be used - contagion of the financial sector with non-performing loans (NPLs percentage share in the assets of the financial sector - NPL / AFS). In the period 2007-2011, this indicator grew rapidly from 3.8\% (2007), 6.1\% (2008), 8.5\% (2009), 9.9\% (2010) to $12.0 \%$ (2011), but has slightly decreased in the last year - $11.8 \%$. It is necessary to bear in mind that the banking assets accounted for over $90 \%$ of the assets of the financial sector in these years, which means that the contagion was spreading on assets of the banking sector with roughly the same rate. 
Vuković V., Domazet l.: Non-performing loans and systemic risk: comparative...

Figure 1. NPL / AFS, NPL / BDP and NPL / Loans in Serbia

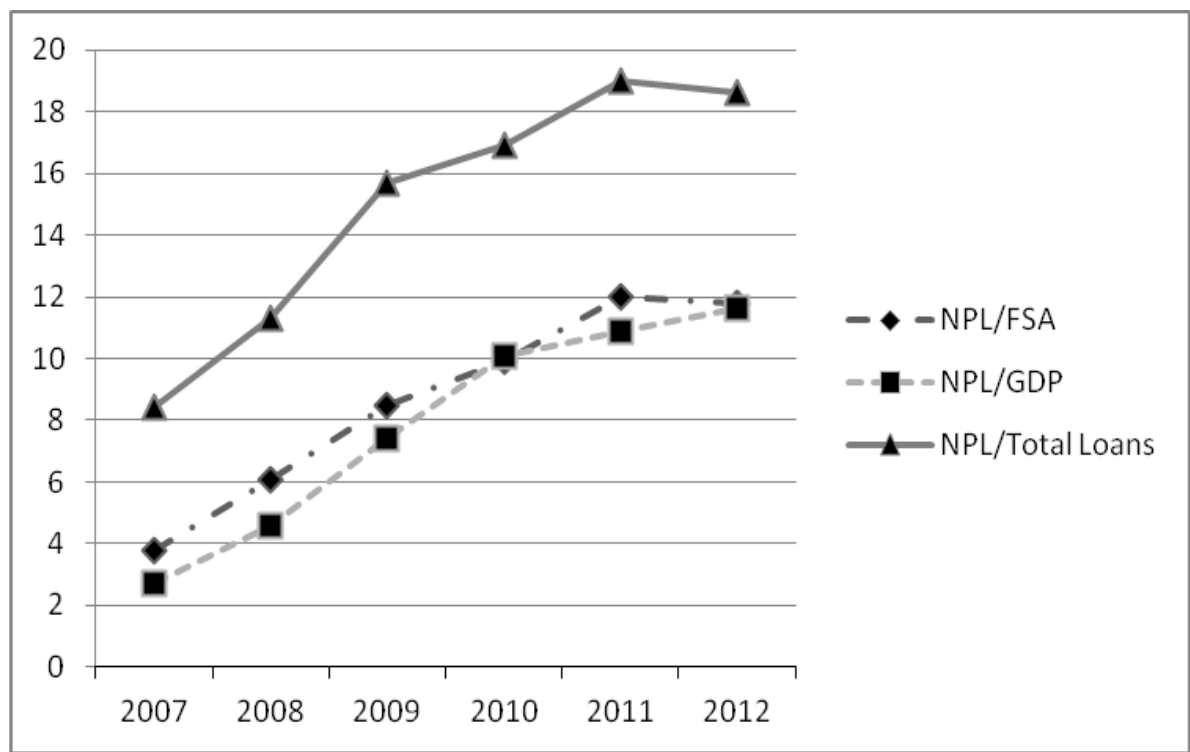

Source: Author calculation based on the World Bank and NBS data.

Graphical representation of these two new indicators (NPL / AFS and NPL / GDP) and the NPL ratio (NPL / Loans) as the most widely used indicator provides visual insight into the correlation and the causal relationship of systemic risk and NPL in Serbia during the period of analysis (2007-2012).

The table shows that the indicator NPL / GDP measures the level of most accurately macroeconomic infection explaining last year's recession. The indicator NPL / AFS indicates the increase in contagion in the financial sector, which was slightly higher than in the real sector due to the feedback effect. NPL ratio rises more rapidly until the end of the recession in 2009 , which was followed by a slowdown that could have fooled the supervisory bodies and lead to the alleviation of prudential measures. The key issue of prudential measures against systemic risk is their exclusive orientation to the banks and the financial sector, while the real sector remains neglected. Therefore, the extension of these measures to the real sector must be considered as the primary innovation

\section{Conclusions}

This study has proven that non-performing loans are the most important source of systemic risk in the domestic financial system and spread of macro- 
Vuković V., Domazet I.: Non-performing loans and systemic risk: comparative...

economic contagion in Serbia. Using a standard NPL ratio showed the extreme exposure to systemic risk, much higher than in the most affected European countries, such as Greece and Ireland. The difference was too high in comparison with other transition countries in Europe as well. On the other hand, the slow rise in the NPL ratio in 2010 and a slight decrease in 2012 did not correspond with the deterioration of macroeconomic performance of Serbian economy, especially with the decline in output and rising unemployment. This was the reason why this paper defined two new synthetic indicators. To measure the propagation of systemic risk within the financial system we used the indicator - contagion with of the financial sector non-performing loans (NPL percentual share in the assets of the financial sector - NPL / AFS), while to assess the potential of systemic risk spillovers to the real sector we used the indicator - macroeconomic contagion with non-performing loans (NPL expressed as a percentage of GDP - NPL / GDP). The empirical analysis confirmed that the indicator NPL / GDP measures the level of macroeconomic contagion most accurately, and explains last year's recession.

The growth of the contagion in the financial sector, which happened to be slightly higher than in the real sector due to the feedback effect, expresses the NPL / AFS indicator. The least accurate is the NPL ratio, whose course could fool supervisory bodies and creators of prudential measures. Finally, it can be concluded that the prudential measures in Serbia, as well as in most other countries, are mainly aimed at the banks and the financial sector. This unilateral approach ignores the feedback effect of systemic risk and reversible course of contagion from the real to the financial sector.

\section{References}

Bank of England (2013). Systemic Risk Survey - Survey Results 2013 H1. Bank of England.

Beck, R., Jakubik, P. \& Piloiu, A. (2013). Non-performing loans: what matters in addition to the economic cycle? Working papers 1515/2013.Frankfurt: European Central Bank.

BIS (2009). Guidance to Assess the Szstemic Importance of Financial Institutions, Markets and Instruments: Initial Considerations. Basel: Bank for International Settlements.

Bordo, M. \& Haubrich, J. (2010). Credit crises, money and contractions: An historical view. Journal of Monetary Economics, 57, 1-18.

Browne, F., Llewellyn, D. \& Molyneux, P. (Eds.). (2011). Regulation and Banking after Crisis. SUERF Study 2011/2. Vienna: SUERF.

Brownless, C. \& Engle, R. (2011). Volatility, Correlation and Tails for Systemic Risk Measurement. Working Paper. New York Univerity.

Buncic, D. \& Melecky, (2012). Macroprudential Stress Testing of Credit Risk: A practical Approach for Policy Makers. Policy research working paper, WPS 5936. The World Bank. 
Vuković V., Domazet I.: Non-performing loans and systemic risk: comparative...

Cao, J. \& Illing, G. (2011). Endogenous Exposure to Systemic Liquidity Risk. International Journal of Central Banking, June 2011, 7(2), 173-216.

Caruana, J. (2010). Systemic risk: how to deal with it? Other publications. Basel: Bank for International Settlements.

Dijkman, M. (2010). A Framework for Assessing Systemic Risk. Policy research working paper, WPS 5282. The World Bank.

EBC „Vienna“ Initiative (2012). Working Group on NPLs in Central, Eastern and Southeastern Europe. European Banking Coordination „Vienna“ Initiative.

ESRB (2011). Annual Report 2011. European Systemic Risk Board.

European Parliament (2009). Defining and Measuring Systemic Risk. Note, 23 November.

Furceri, D. \& Zdzienicka, A. (2011). The real effect of economic crises in the European transition economies. Economics of Transition, 19(1), 1-25.

Group of Ten (2001). Report on Consolidation in the Financial Sector. BIS, IMF \& OECD.

IMF (2010). Systemic Risk and the Redesign of Financial Regulation. In Global Financial Stability Report, April 2010, Chapter 2 (pp. 1-27). International Monetary Fund.

Klein, (2013). Non-Performing Loans in CESEE: Determinants and Impact on Macroeconomic Performance. IMF Working Paper, 72. International Monetary Fund.

Laeven, L. \& Valencia, F. (2012). Systemic banking crises Database: An Update. IMF Working Paper, 12/163. International Monetary Fund.

Mishkin, F. (2007). Money, Banking and Financial Markets. Eighth edition. Boston: Pearson Addison Wesley.

NBS (2013b). Izveštaj o inflaciji - Maj 2013. Narodna banka Srbije.

NBS (2012). Godišnji izveštaj o stanju finansijskog sistema 2011. Narodna banka Srbije.

NBS (2013). Godišnji izveštaj o stanju finansijskog sistema 2012. Narodna banka Srbije.

NBS (2013a). Bankarski sektor u Srbiji - Izveštaj za IV tromesečje 2012. April 2013. Narodna banka Srbije.

NBS (2013c). Tromesečni pregled kretanja indikatora finansijske stabilnosti Republike Srbije - Za I tromesečje 2013. godine. Maj 2013. Narodna banka Srbije.

Nkusu, M. (2011). Nonperforming Loans and Macrofinancial Vulnerabilities in Advanced Economies. IMF Working Paper, 11/161. International Monetary Fund.

Scheiber, T. \& Stix, H. (2009). Euroization in Central, Eastern and Southeastern Europe - New Evidence On Its Extent and Some Evidence On Its Causes. OeNB Working papers, 159. Oesterreichische Nationalbank.

Schreiner, J. (Ed.). (2013). Development in Selected CESEE Countries: Economic Downturn Continues in an Adverse International Environment. Focus on European Economic Integration, Q2/13, 8-19. Oesterreichische Nationalbank.

Vuković, V. (2011). Banking sector: comparative analysis Serbia vs EU Member states. In J. Andrade, P. Teixeira \& M. Radović-Marković (Eds.), Serbia and the European Union: economic lessons from the new Member states, Chapter 18 (pp. 282-296). Coimbra (Portugal) : University of Coimbra - Faculty of Economics.

World Bank. (2013). World Bank/Data/Financial Sector. Retrived from http://data.worldbank.org/ 